\title{
Corporate Governance and Pension Management in Nigeria
}

\author{
OTINCHE Sunday Inyokwe (Ph.D) \\ Department of Public AdministrationIbrahim Badamasi Babangida University, P.M.B 11, Lapai, Niger State
}

\begin{abstract}
Beginning from the 1980s, the public sector in Nigeria was faced with ethical crisis. There were severe economic problems resulting from poor performance of public institutions, poor social services delivery, dwindling cash base and financial sustainability crisis orchestrated by bureaucratic corruption. In the pension subsector, huge pension liability, lack of transparency and accountability and the absence of regulatory and supervisory framework were the characteristic phenomenon. The result was institutional failure and the consequent alienation and dehumanisation of pensioners whose post retirement life became associated with socio-economic slavery. In 2004, the Nigerian government took significant step to transform the pension industry into a viable industry with guaranteed social returns for pensioners via the Pension Reform Act 2004. New regime of pension fund managers was licensed to operate within the regulatory framework provided by the National Pension Commission. In its analysis, the paper appreciates the significant achievement recorded in the pension industry with the introduction of the Pension Reform Act 2004 which set ethical standard for the management of the pension scheme and integrated the private sector in the management of pension funds. The paper in its analysis acknowledged the efficient result achieved so far and called for the strict enforcement of regulatory provisions in the pension industry and civil society activism to strengthen the culture of financial accountability and the sector's performance in alleviating old age poverty among retirees.

Key Words: Pension, Social Security, Retirement, transparency, Corporate Governance
\end{abstract}

\section{Introduction}

Beginning from the 1980s, the ability of the public sector to manage public resources and provide social services efficiently began to diminish. The Nigerian state began to show signs of failure orchestrated by corruption, collapse of public utilities, loss of legitimacy by the military government, loss of public trust and above all moral decadence due to the collapse of moral values. The loss of public trust and confidence transcend every facet of our national life and made efficient service delivery in the public sector a mirage. The inefficiency affected the pension industry where high deficit financing, huge pension arrears and other administrative irregularities were recorded. As a result, many pensioners were owed months of pension benefits. To absolve themselves of any blame, many bureaucrats attributed the crisis in the management of the contributory pension scheme to deficit financing by government and poor record management by pensioners. While this is part of the problem, the major concern lays in the poor attitude of staff of the traditional pension offices to the management of pension finance and pensioners records. Many sharp practices are associated with huge pension liability, diversion of pension funds for selfish ends and the social exclusion or alienation of pensioners became the death trap for pensioners. This ethical crisis undermined the capacity of pension fund to alleviating old age poverty.

The takes a critical look at the Pension Reform Act 2004 to assessing how it has change the culture of financial management in the pension subsector, integrated the private sector into the management of pension funds and redefine the ownership rights in the pension industry for greater efficiency. In its analysis, the paper revealed that the reform of the pension industry via the Pension Reform Act 2004 has increased the rate of capital flow into the pension industry for investment in the financial market and other investment portfolios in the national economy. The Pension Reform Act 2004 introduces a new culture of transparency and accountability criteria that is more efficiency and effective in allocating resources to stakeholders. The reengineering of the pension subsector through corporate governance reforms has strengthen and stimulate macro-economic growth and national development and fire up the financial zeal for alleviating old age poverty among pensioners. However, the value of these gains would be enduring if the alleged cases of deliberate delays in remitting percentage deduction by employers to PFAs and omission of remittances are quickly addressed by stakeholders.

The paper is divided into six chapters. Chapter one introduces the paper with a review of related literature on pension and corporate governance treated in chapter two. The paper addresses issues relating to models of corporate governance in chapter three to create a theoretical platform for the study. Chapter four examined the corporate governance values embedded in the Pension Reform Act 2004 in Nigeria and conclusive remarks are made in section five. 


\section{The Ideological Thinking about Pension}

Two major issues that dominate discussion in this paper are the concept of pension and corporate governance. Explanation on these concepts reflects scholastic orientations.

The word pension has variegated meaning due to its political and economic undertone. Simply put, pension connotes a form of official obligation in any employment relationship. It is a legal and economic obligation in which employers of labour are mandated to fulfil in her contractual relationship with employees. It is a form of employers' benevolence towards employees (Pitch and Wood, 1979) and associated with state welfarism. From this ideological consideration, this paper define pension as a form of compensation paid by employers to labour for years of meritorious services at a point where the value of labour in material reproduction has diminish due to non-progressive health conditions. This definition considers the counterpart funds contributed by employees as savings and not pension. The new pension scheme only enhances the saving capacity of employees. What constitute pension is employers' contribution. Other dimensions of pension scheme allowed the working population to finance the pension scheme in reciprocally beneficial basis. This type of pension scheme addresses the problem of inter-generational equity. The British pension system falls into this category.

One contradictory tend in defining pension lies in the definition given by the Udoji Report of 1974. The report define pension as money withheld during the period of employment and returned with interest to the employee on retirement (Otinche, 2012: 22). The Udoji report provided the base for the Pension Act No. 102 of 1979 which made provision of a public pension scheme that was fully funded by the state and a private sector pension scheme that was contributory in nature. Agblobi (2011) presented the nature of pension scheme in Ghana in his definition as a pre-retirement investment plan and a long-term investment vehicle that is converted into pension income on retirement. He classified the investment plans into state pension, parastatal pension and non-state pension. The later has occupational and individual pension as major components. In line with neoliberalism disposition, Olaniyi (2008) define pension as:

The sum of money paid regularly to a person who no longer work because of age, disablement or to his widow or dependent children by the state, by his former employer from funds to which he and his employees have both contributed.

In any case, one central issue runs through these definitions and this is cessation of work. The eligibility criteria for pension have age as universal requirement. In relative terms, age could mean chronological age which is biological and age at work. The value preference for age at work varies with societies.

In Nigeria, two types of pension scheme are in operation- the non-contributory and the contributory pension scheme. The non-contributory pension scheme was introduced in 1956 via the pension Ordinance of January 1, 1946. The scheme was fully funded by government. Government Ministries, Departments and Agencies (MDAs) were statutorily mandated to incorporate the cost of pension finance into MDAs' annual budget. Indeed, it was funded by $27 \%$ of total emolument of federal employees. In the private sector, it was contributory and employers and employees contribute $6.5 \%$ and $3.5 \%$ respectively into the pension fund account initially managed by the National Provident Fund (NPF) and later by the National Social Insurance Trust Fund (NSITF). Under the neo-liberal arrangement, the rate of contribution has been unified. Both employers and employees make $7.5 \%$ contribution as pension fund. This has been the practice in the public sector since June 2004 when the sector was reform in Nigeria.

The eligibility criteria for the enjoyment of pension rights under the non-contributory pension scheme were spelt out. An employee is employed at age 16 and retires voluntarily at age 45 or compulsorily at age 65 and or after 35 years of service. The Pension Reform Act 2004 increased the voluntary retirement age to 50 years and left compulsory retirement age at 65 years. Those who were left with three years or less to retire as at June 2004 were exempted from the contributory pension scheme (Abari, 2003; PRA, 2004). The pension benefits of these categories of employees are managed under a transitional arrangement that guarantee 5\% funding from the Federal Government. The transitional funding structure is managed by the Central Bank of Nigeria (CBN) where it is used to purchase the Retirement Benefits Redemption Bond to be sold at the time of retirement of each employee and the proceeds paid to him/her as pension. The management of pension fund with generative promissory notes for workers welfare is interfaced with corporate governance values. From the legal initiative that gave birth to the scheme to the creation of institutions that effectuate pension benefits administration, corporate governance values inundate the scene. The management of pension funds under any funding structure draws the line of efficiency to corporate governance practice. Pension administration reflects greater concern of employers to workers.

\section{Debates on Corporate Governance}

Corporate governance emerged from the ideology of governance. Governance in general terms reflects an existing mode of policy initiation, formulation, implementation and adjudication on public policies with a 
view to generating favourable outcome for members of a society. Such practices often generate assessment quotas from the public as bad or good governance. Governance is a product of public trust and obligation. The task of governance became so enormous that the private sector has to be incorporated into the general framework of public sector governance for improved efficiency. The institutional autonomy granted to pull private and public resources together results from corporate trust and corporate ability.

Discussion about corporate governance has attracted wide intellectual discussion because of the concern to set the best standard for the efficient management of public resources. Particularly in third world countries, the mismanagement of public resources has generated poor policy outcomes due to defective institutional values where lack of transparency and accountability and poor monitoring and regulatory frameworks have affected the process of social development. Against this background, many international organisations have set minimum standard for the management of financial resources in public and private sector organisations. Most significant are the efficiency benchmark set by the Organisation for Economic Co-operation and Development (OECD), the World Bank (WB), the International Monetary Fund (IMF), Global Corporate Governance Forum (GCGF), Trade Unions (TU), Civil Society Organisations (CSOs), International Standard Setting Bodies (ISSBs), Transparency International (TI), International Financial Reporting Standard Board (IFRSB) and the European Council among others. These standards are geared towards addressing the systemic dislocations in the management of corporate resources so that desirable outcomes could be generated for the citizens (especially retirees). The first target is to build corporate trust among company managers, board members, shareholders and stakeholders and provide the structural framework for organisational efficiency. The concern of this paper is to place corporate governance standards within the institutional and legal framework provided in Nigeria to facilitate the efficient management of pension fund and pension assets. Corporate governance practices facilitate the attainment of the vision and mission statement of organisations. As argued by Rachel (n.d:2) good corporate governance practices instil in companies the essential vision, processes and structures to make decisions that ensure long term sustainability. Primary in corporate governance practice is the achievement of political, social, and economic goals.

The Economic Commission for Africa report (ECA, 2005:3) defines corporate governance as the mechanism through which private or state owned corporations and their management are governed. This mechanism provides the structure through which the objectives and the performance of a corporation are determined and monitored. Implicit in ECA definition is the submission that corporate governance promote the efficient mobilisation and allocation of capital, improve assets monitoring mechanism and improvement on the micro and macro economic performance. Given the dilemma of economic underdevelopment in Africa in general and Nigeria in particular, the Economic Commission for Africa (ECA) has task itself to ensuring that it:

i. Promote greater good governance in the financial sector and state-owned enterprises;

ii. Promote the need for an outline of shareholders' obligations;

iii. Promote the importance of governance in small and medium scale enterprises as key to economic growth and development; and

iv. Emphasized the importance of governance in poverty alleviation in Africa (ECA, 2005:3).

The prudent management of national resources is central to the alleviation of poverty in Africa. For instance, in spite of the enormous wealth in Nigeria the level of poverty is still very high. The rate of poverty has risen from $28.1 \%$ in 1980 to $54.4 \%$ in 2004 and the rate of inequality from $0.43 \%$ to $0.49 \%$ in 2004 (UNDP, 2009: 49; 64). This underscores the fact that the efficient management of national resources is a dependable variable in the alleviation of poverty, reduction of inequality and sustainable development of Africa in general and Nigeria in particular. This attracted the attention of African leaders in international forum like the African Peer Review Mechanism (APRM), the African Growth and Opportunity Act (AGOA), the Millennium Development Goals (MDG) and the New Economic Empowerment and Development Strategy (NEEDS) among others. It her report, APRM (APRM, 2008:32) observed that sustained efforts should be made to improve corporate governance with a view to creating wealth and alleviate poverty in Africa. The APRM is an institutional framework designed by African leaders to promote policy reforms and entrench best practice standards that would facilitate economic growth, sustainable development and promote political stability. The primary objective is to promote economic governance, political governance, corporate governance and socio-economic development. These same goals formed the cardinal objectives of the New Partnership for African Development (NEPAD, 2006:28-29). The author of this paper argue that corporate governance creates a synergy between capital inflow, efficient enterprises management, wealth creation and employment generation under a catalytic framework of efficiency of administration and minimal degree of corruption and economic waste. The ultimate goal of corporate governance is to reduce the cost of governance through stakeholders and shareholders involvement in enterprise funding and strategic decision making processes. In this paper I tend to argue that corporate governance reform is a paradigm shift and an ethical revolution in the field of management. However, its success is challenged by many factors: 
i. It has increased the dependence on external loan as a veritable source of financing development projects. International capital is sourced for at huge cost to the state to finance corporate governance reforms and stimulate political and economic growth;

ii. Lack of an effective and efficient regulatory framework;

iii. Lack of public confidence in some reform areas like it is in the pension industry;

iv. Lack of psychological (attitudinal support) drive to facilitate the success of the reform measures;

v. Lack of reliable energy supply for efficient production and distribution of goods and services;

vi. Lack of positive reinforcement on existing industrial, material and human capacities;

vii. Poor integration of host communities (rural areas) into the framework of corporate governance;

viii. Less involvement of the civil society in the reform process;

ix. Weak political will to enforce transparency and accountability standards; and

$\mathrm{x}$. The sale of corporate assets to cronies or major financiers of the ruling political party. These cronies or party men undermine any ethical standard set for enterprise efficiency and growth and worse still vandalized rather than improve on originally installed industrial capacity.

These factors underscores the fact that corporate governance work with concentric variables like political will, economic discipline and socio-cultural tolerance. Political will set the legal standard for the enforcement of economic discipline which in turn provides the invisible laws that facilitate community-enterprises relations. Socio-cultural tolerance placed premium on good neighbourly relations between the host community and organisations. The healthy interface of these variables with each other provides corporate legitimacy for government and organisations.

According to Akinboade in (ECA, 2003:67), corporate governance is:

The manner in which the power of a corporation is exercised in the stewardship of a corporation's total portfolio of assets and resources with the objectives of maintaining and increasing shareholders value and satisfaction of other stakeholders in the context of its corporate mission.

Corporate governance implies the entire network of formal and informal relations involving the corporate sector and their consequences on society in general (Keasey, Wright and Thompson, 2007). Blair (1995) is of the opinion that corporate governance encompasses:

The whole set of legal, cultural and institutional arrangements that determine

what publicly traded corporations can do, who controls them, how that control is exercised and how the risks and returns from the activities they undertake are allocated.

It is the structures, process, cultures and systems that engender the successful operation of organizations (Keasey and Wright, 1993). It emphasizes the separation of ownership and control and the impact of corporate behaviour and investment decision making on a competitive market economy. Such corporate relationship and inbuilt institutional safeguards created by government strengthen institutional capacity in the management of public resources, information flow and financial disclosure and attracts international capital into the economy. In pursuit of these goals, the OECD (OECD, 2003) provided legislative and regulatory guidelines for countries to work with. Notable of these guidelines are the promotion of transparent and efficient market in line with the rule of law, the promotion of the rights of shareholders and business owners, equity in the treatment of shareholders, the mutual co-operation between business owners and shareholders in wealth and job creation and commitment to the financial solvency of the enterprise. Others are disclosure and transparency and the effective monitoring of management by the board whose functions are clearly defined by the legislative framework provided by national government. These principles are geared towards promoting sustainable corporate financial structure.

In establishing universal standard for corporate governance practice, the dilemma in corporate governance practice across markets is not ignored. The dilemma results from technological changes, distinctive historical, cultural and institutional specificities with objectively distinct market value relations. On this premise, Clarke and dela Rama (2008) identified different but competing corporate governance systems in the market-the Anglo-American system, the European relationship based system and the relationship based system of the Asia-Pacific. In recognition of this distinctiveness, OECD recommended the adaptation of corporate governance standard to domestic conditions. This flexibility according to Clarke and dela Rama (2008) would encourage easy adaptation to changes in technology, trends in competition, optimal firm organisation and vertical networking patterns. This ostensibly promotes efficiency.

The efficiency profile provided by Berle and Means (1932), Alfred Marshal (1920) and Adam Smith (1776) on the separation of beneficial ownership and executive decision making are invariable promotes of organisational performance. These scholars are all agreed that societies governed by corporate governance values are purveyors of organisational performance. Their concern emanates from the revealing inadequacy of traditional economic rules that were yielding little result in the emergent economies governed by negative trends 
of globalization. Such traditional concern like the management of pension funds by government, the resultant low liquidity ratio and huge pension liability generated inefficient result that fall short of the scale of retirees' welfare needs. However, with the reform in the financial market, stock option has progressively offered rewards for pension funds and motivated pension funds administrators (PFAs) to take investment risk for corporate growth and benefits administration for retirees. Legal guarantees have made the PFAs to be transparent and accountable to the regulatory authority and contributors through open information disclosure system. This has generated corporate trust among stakeholders in the pension industry in Nigeria. The liquidity ratio of the PFAs is highly dependent on rates of contributions by individual employee whose business trust and contributions sustains the viability of the pension industry. Rates of contributions, the liquidity of the PFAs and investment returns are the financial tripod upon which the contributory pension scheme stands. models.

Applying corporate governance values to market dynamics has been justified by many theoretical

\section{Models of Corporate Governance}

Discussion about corporate governance has been modelled into different schools of thought. These are the principal-agent or finance model, the myopic market model, the abuse of executive power model otherwise known in this paper as the executive arrogance model and the stakeholder model. Each of these models had seemingly divergent views about corporate governance.

\section{The Principal-Agent or Finance Model}

This model articulated by Hart in 1991 recognised the restraining power of the market for capital, managerial labour and institutional regulation on managerial discretion. It emphasizes the residual voting rights of shareholders and its influence on the use of corporate resources to secure value maximizing ends. This model assumed that corporate governance (CG) instruments are the outcome of the bargaining process between management and shareholders. It relied on the supposition that ex-post external intervention distortion market conditions but veered into consideration that the monitoring and bonding expenditure paid out to align the behaviour of the manager-agent with the interest of owners-principal is economic liability to the economic subsystem. However, such costs are innovative measures in corporate governance practice. The model opined that developments in the managerial labour market in relation to executive stock options, the market for corporate control or leverage and management buy-outs are organisational response to deficiencies in corporate institutions.

The principal agent model recognised the absence of monopoly power or negative externalities as catalyst for profit and social welfare maximization. The separation of ownership and control allows managers to deviate from profit maximization and allows the owner manager to sale equity to outsiders and consequently bear the cost of equity dilution. The primary principles of corporate governance such as board members accountability to shareholders, elected non-executive directors and independent auditors are seen as products of the initial sale of equity. The sale of equity integrated future managers into the monitoring and accountability framework and increases the firms' market value and profit. This model recognized the role of shareholder to vote in the organisational decision making process i.e. shareholders participation in corporate governance practice. This has entrenched a culture of transparency, accountability and information disclosure about the firm's operations. The model acknowledges the fact that monopoly investment by investor damages market liquidity and this is largely responsible for corporate inefficiency. This can be corrected by removing restrictions on factor market and corporate control. The increased involvement of institutional investors encourages insider practices. The introduction of extra shareholder cost depresses the floatation price to the detriment of newcomers seeking outside equity.

\section{The Myopic Market Model}

This model is a critic of the principal-agent model. The basic assumptions of the model are that shareholders welfare is different from share price maximization as the market systematically undervalues longterm expenditure on capital project and research and development spending. On this note, diligent managers respond to market forces by taking economic decisions that align with the prevailing share price or risk the threat of hostile takeover. This model sees short-term investment as a consequence of market failure (Charkham, 1994; Sykes, 1994 and Blair, 1995). The myopic model rests its argument on five basic assumptions:

a. The cost of capital is too high. Higher cost of capital in a particular market propels a rational manager to extend his investment tentacles to other product markets;

b. Irrespective of the true cost of capital, financial accounting practices within the firm give rise to high rate of returns requirements or unrealistic short-pay-back period; In this consideration, managers are appointed and rewarded based on their short- term performance.

c. The stock market is overly concerned with short-term performance; 
d. The stock market misprices assets and experiences fashion and fads without any corresponding changes in underlying fundamentals; and

e. Hostile take-over plays an important role in the market. However, hostile takeover may become a source of distortion or distraction from the task of value creation (Zimmer 1989).

Proponents of this model advocate the increase in shareholders loyalty and decision making power and the placement of restriction on shareholder exit. They recommend the encouragement of relationship investing through long-term investment, restrictions in voting rights for short-term share holders as well as the empowerment of employees and suppliers presumed to have long-term relationship with the firm. The major shortcomings of this model is that it increase the cost of shareholders exist and impede the take-over process, increase the vulnerability of business owners to managerial self-serving interest and weaken the power of sanction against such behaviour.

\section{The Abuse of Executive Power / Executive Arrogance Model}

This model otherwise described by this paper as the executive arrogance model is concerned with the abuse of power by corporate elites. Under this model of corporate governance, power is concentrated in the hands of senior managers who used it for selfish ends. Arising from this consideration, Hutton (1995) concluded that such executive behaviour threatened the interest of shareholders, organizations and the society at large. My opinion is that the use of corporate assets for selfish end by corporate elite would become a phenomenon where there is elite conspiracy to subvert the corporate governance efficiency system. However, Hutton argued that this can be checkmated by elected non-executive directors, the audit process and the threat of take-over. This is because shareholders who are protected by liquid assets market and operating as fund managers are not interested in substantial abuses.

The model view share options as the breakdown of corporate governance and this increases the propensity of managers to arbitrarily increase their remuneration. As Kay and Silberston (1995) put it, many companies are dominated by a board that acts as self-perpetuating oligarchy. They regarded senior managers as the governing elites who are corrupt and dictatorial. According to Hutton (1995), the emphasis on enterprise culture or free market has weakened traditional ethical constraints and created room for senior managers to increase their pay irrespective of the prevailing share prices. The only restrain on executive pay is the modesty of the executive themselves. On this note, Kay and Silberston (1995) suggests the weakening of the entrenched position of the senior corporate elite by limiting their appointment to a tenure of four years, independent numeration of non-executive directors and greater power for non-executive directors.

\section{The Stakeholders Model}

This model is also a reaction to the principal-agent model that is laden with descriptive, predictive and normative values. According to this model, the function of a firm transcends the maximising shareholders' welfare. Welfare maximisation for clients promotes equity and social justice. The presuppositions primary to this model is:

a. Firms with a reputation for ethical treatment of clients and employers build up trust relations that encouraged profitable investments and beneficial exchanges;

b. Stakeholder's involvement is high where firms clearly and widely defined her corporate goals (Jahns 1995). This eventually leads to success derived from ethical behaviour like truth telling which reduces the cost of social association. According to Arrow (1972) truth telling is a social good. However, telling lie may benefit individuals and increase the cost of information gathering if told in a consistent manner. This implies that there is co-operative game or prisoner's dilemma in economic relationships. Full co-operation maximizes participants' joint pay-off and cheating a dominant strategy in a one-short game. Corroborating Arrow, Keasey, et al (2007) observed that firms which have build a reputation for ethical collaborations over long period substitute co-operative outcomes for fraudulent practices. Firms which have established such a reputation are likely to attract all categories partners. Its ethical behaviour maximizes long term profit especially where cheating is the most profitable game. To sustain ethical behaviour, tangible association or relationships between the firms, its trading partner and its employees it is necessary to build a trust relationship and guarantee longterm contractual relationship. On the whole, the model see firms as social organizations where decisions are traditionally made to safeguard employee's interest.

\section{Corporate Governance and the Pension Reform Act 2004}

Three tier funding structure exists in the pension industry in Nigeria. The first tier funding structure government exclusively fund the liability 1 category of pensioners. Governments make $27 \%$ budgetary allocation of the total emolument of civil servants for the payment of pension benefits. This funding structure is non-contributory and covers worker who had retired before June 2004. The second funding regime is contributory in nature and employers and employees make $15 \%$ (7.5\% each) contributions to the pension fund. 
Before their exemption from the contributory pension scheme in 2012, Armed forces personnel contributed $2.5 \%$ and government $12.5 \%$. Transitional provision has been made through bond purchase for those exempted from the new scheme (PRA, 2004). The third funding structure covers those with less than three years to retire. Their retirement benefit is funded via 5\% total emolument contribution by government into the retirement benefit redemption bond account managed by the Central Bank of Nigeria. There is no doubting the fact that the new pension scheme has reduced the financial burden of pension financing on government. The financial burden resulted from government's funding of liability I, liability II and liability III categories of pensioners. Liability I pensioners are pensioners under the old pension scheme, liability II are those exempted from the new scheme and liability III are those who transited to the new scheme (Otinche, 2009).

The efficient management of these funds results from the change in governance culture transparency, accountability, efficient supervision or regulation, board membership independence and responsible leadership forms the hallmark of business success. The PRA 2004 has made provisions for organisational value system that promotes dispersed ownership rights and efficiency standard in pension fund management.

Modules of Transparency: Transparency was not emphasized in business management until the 1930s when the world economy experienced its first economic depression. The stock market collapse of 1929, 1987 and 2008 limited the prospect of the financial market in stimulating economic growth. The stock market collapse of 1929 led to government regulation of the financial market through the Securities and Exchange Commissions. The establishment of the Securities and Exchange Commission (SEC) in 1979 in Nigeria to regulate the financial markets has reduced incidences of fraud in the financial market that offered investment outlets to pension fund managers. The introduction of automated trading system and the Central Security Clearing System (CSCS) has promoted efficiency of financial transactions. This has had positive effect on pension funds investment and investment returns on equity instruments.

Transparency encourages freedom of action that generates public trust in information management. Information disclosure about market relations, risks and market potentialities are strategic to the efficient management and viability of the pension industry in Nigeria. In the past information about employees bio-data were fraudulently managed leading to conspiracy in bureaucratic actions. Information disclosure about pension fund account and investment returns if any were not open to public scrutiny. Pension funds management was shrouded in secrecy and access to information relating to pension fund management for academic research purposes was difficult. The conspiracy of bureaucratic action resulted to the ghost pensioners' syndrome, underpayment, over-payment and omission of pensioners name from the pension payroll. Those saddled with the responsibility of managing the pension funds for liability 1 categories of pensioners misappropriated the trust funds. The preliminary reports submitted by the Pension Reform Task Force set up by President Goodluck Jonathan in 2012 reported that about 44, 320 pensioners that retired between 1968 and 1975 were never paid any pension benefit as at 2012. The task force uncover about one hundred and fifty one billion (N151billion) naira pension fund starched in sixty six (66) illicit bank accounts in Nigeria (Otinche, 2012). Presenting, eight (8) persons are standing for embezzling thirty three billion (N33 billion) naira upon which an assistance Director John Yakubu Yusuf has been prosecuted for embezzling the sum of N1.4 billion naira of the pension fund meant for the Police Pension Office. These incidences reflect the degree of corruption in the Nigerian society and the enslavement of labour by labour.

Under the PRA 2004, a custodian relationship exists between the pension fund administrator and pension fund custodian and this erode the basis for exclusive control and manipulation of pension fund by a single agent for selfish ends. The accounts of contributors and the Pension Fund Administrators/Pension Fund Custodians are closely monitors by the National Pension Commission. The statement of account of the PFAs are periodically audited and published. Guidelines have been put in place for the equitable distribution of investment returns and benefits in line with the principle of social justice. Contributors are paid $97 \%$ of investment returns on net asset value, the PFAs takes 2\%, PFCs 0.6\%, Closed Pension Fund Administrators $0.2 \%$ and the National Pension Commission takes $0.3 \%$ (Otinche, 2012).

\section{Accountability Criteria}

Globally, accountability has become the hallmark of good business practice. Business organisations are required to maintain high level of financial accountability in line with the International Financial Reporting Standard Board (IFRSB). The goal of IFRSB is to promote the efficient allocation of capital, increased transparency, reduced complexity in financial reporting and improve business efficiency (IFRS, 2009:4). IFRSB established generally accepted accounting principles with a single set of high quality, understandable and enforceable global financial reporting and accounting standards that promote business growth. In furtherance of this course, the Federal Government of Nigeria signed into law the Financial Reporting Council Bill (William, 2011:4) in 2011 to enhance access to reliable financial information and improve audit quality and promote foreign direct investment to Nigeria.

Before the reform of the pension subsector in 2004, some Ministries, Department and Agencies (MDAs) granted the right of hold of pension funds to accredited underwriters like NICON Insurance and Niger 
Insurance among others. The pension funds were paid directly by government into the account of the underwriter to hold in trust for employees of the affected MDA. This culture of pension fund management was associated with fraud and was not open to public scrutiny. The result was systemic infractions into pensioners' funds. To correct this anomaly, the Pension Reform Act 2004 introduced a network of accountability criteria where employees are mandated to open retirement saving account with any PFAs of their choice. The employer deducts at source the $15 \%$ employer/employees' rates of contribution and remits it into employee RSA held by the pension fund custodian (PFC). Statutorily, this transaction is done within 7 days of the payment of employees' salary. Upon receipt of the fund, the PFC notifies the pension fund administrator (PFA) of the receipt of such contribution within 42 hours. Failure to do so attracts sanction either for the employer or the PFC.

The PFAs and PFCs mandatorily keeps proper books of account and records of the income, expenditure, assets, the investment and investment returns for all transactions relating to pension fund assets. Those accounts are periodically audited by a team of internal and external auditors. The audit report is submitted to the National Pension Commission within 120 days from the end of a fiscal year. Such audited account is equally published in two national dailies within one month of the approval of such audited account by the commission. The audited account is published or displayed in all regional offices of the PFAs and or PFCs within 30 days of approval (PRA, 2004). For efficiency of fund administration, fund Transfer between the PFAs and the PFCs is done through the Nigerian Inter-bank settlement system (NIBSS). Each PFA and PFC is required to submit an annual report of the preceding year to the commission within four months from the end of a fiscal year (PRA, 2004). Guidelines for information disclosure and auditing are provided to protect contributors' funds. This mode of accountability criteria has instilled a sense of financial discipline on the management of pension funds in Nigeria and led to the injection of $25.0 \%$ of pension fund into the capital market in 2007 thereby increasing capital market liquidity. This has generated positive growth returns in the economy.

Institutional Regulation: One of the major shortcomings of the Pension Act No. 102 of 1979 was its inability to make provision for a regulatory framework in the pension sector. The PRA 2004 created legal instruments for corporate supervision of the pension industry. The PRA 2004 empowers the National Pension Commission (PENCOM) to:

i. Establish standard rules and regulations for the management of the pension funds;

ii. Investigate any PFAs and PFCs involve in the management of pension funds;

iii. Impose administrative sanctions or fines on erring employers or PFAs or PFCs;

iv. Charge and collect such fees, levy or penalties as occasion demands; and

v. Formulate, direct and oversee the overall policy in the pension industry in Nigeria (PRA, 2004). This stream of supervision and regulation has instituted a culture of transparency and accountability in line with the fiscal responsibility framework of the federal government of Nigeria. Act of dishonesty, fraud, bribery, misappropriation of assets or contributions, default payment and other acts of administrative inactions that do not promote economic efficiency in the pension sector are queried by the National Pension Commission (Otinche, 2012). Institutional regulation is enhanced through whistle blowing by agents of the civil society.

Institutional Leadership: This section takes a critical look at the impact of leadership on setting agenda for corporate governance practice. The ethical values emphasized by corporate governance are products of leadership initiatives and leadership integrity. Generally, the dearth of leadership integrity has produced a chain of social vices like fraud, cheating, dishonesty, poor commitment to work, lack of identification with organisational goals and manipulation of institutional resources for selfish ends. To avoid these ethical dilemma calls for prudent disposition from leaders, tactfulness, courageousness, sincerity, truthfulness and commitment. Such qualities are instrumental to institutional success at any unit of administration. Strategic decision involving the separation of beneficial ownership from executive control, moderation of the residual voting right of shareholders, commitment of resources to value maximizing ends, identifying prospective markets and labour resource re-enforcement are derivatives of leadership enterprise. The monitoring and bargaining process between corporate insiders and outsiders requires functional and progressive leadership initiative which underscores the imperative of corporate control, the prioritisation of investment needs and identification of investment outlets as well as investment in riskless or less risky asset classes. Diversification or hedging options are easily applied where there is a team of dynamic leadership whose decisions responds swiftly to market dynamics. These are preliminary benefits offered by the PRA 2004 today.

Overall, the investment of pension funds in equity instruments makes contributors secondary shareholders in companies. As primary shareholders, the PFAs (representatives of the secondary shareholder) moderate investors-shareholder relationship and create corporate governance balance that generates positive impacts on the development of the pension industry. Recognising the command position of leadership in the management of pension fund and the tendency to abuse the power bestowed on them, the PRA 2004 prohibits any leadership of a PFA from selling pension fund assets to itself and staff. They are as well prohibited from 
investing pension fund asset in equity instruments of a company they have more than $10 \%$ equity interest in. Pension fund cannot be tendered as collateral foe bank credits.

Independent of the Board: The Pension Reform Act 2004 changed the context of board membership in the pension industry. Except for the pension transitional departments, the PRA 2004 made provision for representative board membership and the promotion of executive directors' accountability to shareholders. The board of the PFAs/ PFCs periodically sets priorities and defines policy goals that serve the strategic interests of stakeholders. They do not compromise official standard on policy decisions relating to business management. The role of the board in taking strategic decisions and its outcome is acknowledged by Baysinger and Hoskisson (2008) and Stiles and Taylor (2008) and this becomes the yardstick for assessing the corporate performance of board in areas of finance, strategic customer relations, risk management operations, human resources, ethics and innovation (Epstein and Roy, 2008). These strategic functions are performed with optimal result when board members are paid reasonable sitting allowances that are commensurate with their responsibilities. This could realistically be achieved if political consideration is not the determinant for board member appointment as was the case under the non-contributory pension scheme. Those appointed into the boards of transitional pension departments are predominantly supporters of the ruling People Democratic party. Such board members may likely compromise the performance standard irrespective of the degree of compensation awarded them. Board member compensation is emphasized by the Cadbury Report (1992) and the Greenbury Report (1995). The Cadbury report advocated the establishment of remuneration committees made up of non-executive directors to determine directors' pay. This committee chaired by non-executive directors ensures that management reward system is tied to effective performance and reassures shareholders of transparency in the pay system administration. The view of Fernandez and Arrondo (2008) attest to this fact. In another dimension, the payment of bonuses to managers is not conditioned on loan profitability created in the early years because of the difficulty of assessing the inherent risk potentials of such investment decision at the initial stage.

There is an interrelationship between the above argument and board member relations in Nigeria. The National Pension Commission is overseen by board members appointed by government on a terminal basis. As well, the PFAs and PFCs are overseen by board members whose business relationship with government is not feeble. The board members provide the general policy guidelines for the operations of the stakeholders in the pension industry.

Eternal Vigilance: Advocates of corporate governance have undermined the role of the civil society in promoting good governance. Eternal vigilance engineered by civil society organization like pensioners' association could buoy up organizational efficiency. Civil society organisations (CSOs) activism is a trigger to public accountability on the activities of company directors, board members and other stakeholders. The PRA 2004 made provision for whistle blowing by a compliance officer and members of the civil society and this has acted as a check on leadership exuberance. However, the compliance officer who is an employee of the PFA may be constrained to report his employer as he who pays the piper dictates the tune. I have recommended in my earlier study that the compliance officer should be an employee of the National Pension Commission if his role of whistle blowing is to be made effective. The weak custodial action taken against John Yakubu Yusuf, the Chief Accountant of the Police Pension Office on January 28,2013 for embezzling the sum of one billion four million (N1.4 billion) naira (Azu and Mutum, 2013) generated negative reactions from members of the civil society. He was sentenced to two years imprisonment with an option of a fine of seven hundred and fifty thousand naira. At the time of forwarding this paper for review it was not certain if the court judgement will be set aside following the protest by civil society agents under the leadership of Dino Melaye.

Ownership Rights: The PRA 2004 has dispersed the ownership rights and broadened the scope of participation and investment in the pension industry. Regulatory guidelines issued by the National Pension Commission in December 2008 made provision for the participation of expatriates and Diaspora staff and the informal sector workers in the contributory pension scheme (Otinche, 2012). Social security benefits are transferred from the host country to the parent country of a worker. There is clear definition of ownership rights by the PRA 2004. This is accentuated by financial globalisation and the revolution in information technology that has facilitated labour and capital mobility, the exchange of goods and services as well as the building of mutual trust and co-operation on social security matters (Otinche, 2012).

Overall, corporate governance practice requires the active participation of all stakeholders in business management directly and indirectly. Significantly, the ethical standard set for the pension industry by the PRA 2004 under the tutelage of the National Pension Commission (PENCOM) has moderated managers-investors (contributors) relationship and enhanced corporate relations that have generated positive growth returns in the financial market, the pension industry and the economy at large. Implicitly, companies where pension funds are invested in are closely monitored to assess the viability of its stocks. The regime of information management (disclosure) in the pension industry, the capital market and the economy in general has improved significantly. In spite of these good development, delay in the remittance of the $15 \%$ counterpart funds and omission in 
monthly remittances by employers of labour and the inadequate provisions made for the participation of informal workers in the contributory pension scheme have inhibit the prospective growth of the pension industry in Nigeria. the non-contributory pension scheme is still faced with financial crisis resulting from unethical conduct by officials in the transitional pension offices.

\section{Concluding Remarks}

Strategic business management the world over has advocated the introduction of corporate governance value as an ingredient of economic efficiency. The failure of public institutions in many parts of the world like the U.K, USA, Japan and Nigeria among others has led to the reform that enhance institutional capacity to manage public resources. This governance culture has change the face of business relations and injected new value system into the public and private sector mode of resources governance in Nigeria. This remedial measure has reduced the problem of gross inefficiency in the public financial management. In the pension industry, it has addressed the challenges of deficit funding, increased pension liability and poor management of pension records and pension funds. The lack of transparency and accountability, poor monitoring, control, supervision characteristic of the past has been minimised. Care should be taken so that the new pension scheme will not be placed in financial jeopardy. Therefore, the board that oversee transactions in the pension industry should comprise men of moral integrity to define, enforce and transform the mechanics of leadership entrepreneurship in the industry for optimal performance.

Advocates of corporate governance are not mistaken on its benefit to the business world. Stakeholders in the pension industry should abide strictly by its basic principles identified in this paper. Its strength in promoting business integrity cannot be wished away easily. Pension fund administrators should be transparent in their dealings with other stakeholders especially funds contributors. The resultant trust relationship will encourage contributors to make voluntary contributions that will increase the liquidity ratio of fund managers. The auditing of pension account by external auditors and the circulation of annual reports to all stakeholders is a catalyst to business trust and economic growth. This should be given more impetus. The national pension commission should not compromise in its regulatory and supervisory functions as this will breach the ethical standard set by the Pension Reform Act 2004. Board members should be proactive and upright in addressing the challenges confronting the pension sector. The independence of board members is a prerequisite to the exercise of effective control over the executive members of the National Pension Commission and other subsidiary services providers. Civil society agents should be more proactive in their whistle blowing activities as this will stimulate efficiency of administrative action from the supervisory agents and fund managers.

\section{Bibliography}

[1]. Abari, T.T.T. (2003), "Briefs on the Computation of Harmonised Pension Scheme Revealed" Interview with Yilma,J.M. in Establishment and Pension Bulletin, March. P.9

[2]. African Peer Review Mechanism (2008), Comments of the Government and People of Nigeria on APRM Country Review Report, No.8 June Agblobi, A.D. (2011), Pension: The New Investment Perspective for Retirement Planning,Accra. Mork Impression. P.1

[3]. Azu, C.J. and Mutum, R. (2013), "Pension Scam: Accountant Who Stole N1.4bn Freed on N750, 000 Fine" Daily Trust, January, 29

[4]. Berle, A. and Means, G. (1932), The Modern Corporation and Private Property, New York. Commerce Clearing House.

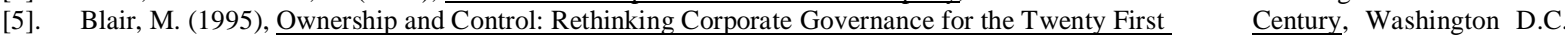
Brooking Institutions.

[6]. Baysinger, B. \& Hoskisson, R. E. (2008), The Composition of Boards of Directors and Strategic Control: Effect on Corporate Strategy, in Clarke, T. and dela Rama, M. (eds) (2008) The Fundamentals of Corporate Governance, London. SAGE Publications. Pp. 66-83

[7]. Cadbury, A (1992), Corporate Social Responsibility, in Clarke, T. and dela Rama (eds) (2008a) The Fundamentals of Corporate Governance, London. SAGE Publications. Pp.24-39

[8]. Cadbury, A. (2008), The Chairman and the Chief Executive, pp.111-128 in Clarke, T. and dela Rama, M. (eds) (2008b) The Fundamentals of Corporate Governance, Volume 2: Boards and Directors, SAGE Publications, London

[9]. Charkham, J. (1994), Keeping Good Company: A study of Corporate Governance in Five Countries, Oxford. Oxford University Press.

[10]. ECA (2005), Economic Commission for Africa and Corporate Governance, Lusaka, ECA. December

[11]. Epstein, M.J \& Roy, M.J. (2008), Evaluation and Monitoring CEO Performance: Evidence from US Compensation Committee Reports in Clarke, T. and dela Rama, M. (eds) (2008), The Fundamentals of Corporate Governance, Volume 2: Boards and Directors, SAGE Publications, London

[12]. Fernandez, C. and Arrondo, R. (2008), Alternative Internal Controls as Substitutes of the Board of Directors, in Clarke, T. and dela Rama, M (eds) (2008), TheFundamentals of Corporate Governance, Volume 2: Boards and Directors, SAGE Publications, London. Pp. 52-65

[13]. FRN (1974), Public Service Reform Commission Main Report (Udoji Report), Lagos. Ministry of Information Printing Press. P. 172

[14]. IFRS (2009), Guide to International Financial Reporting Standards, Center for Audit Quality, September Hart, O. D. (1995a), Firms, Contracts and Financial Structure, Oxford. Clarendon Press. Pp. 678-689

[15]. Hart, O. D. (1995b), "Corporate Governance: Some Theory and Implications” Economic Journal, 105.

[16]. Hutton, W. (1995), The State We're in, London. Cape

[17]. Jones, T. M. (1995), "Instrumental Stakeholders Theory: A Synthesis of Ethics and Economics" Academics of Management Review. 20. Pp.404-437

[18]. Keasey, K., and Thompson, S. and Wright, M. (2007), Corporate Governance, New York. Oxford University Press. P. 2 
[19]. Keasey, K. and Wright, M. (1993) "Issues in Corporate Accountability and Governance" Pp. 291-303

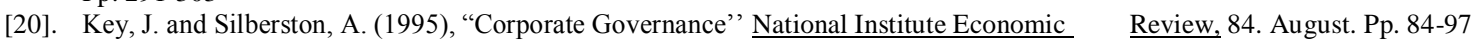

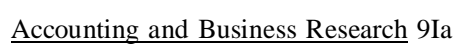

[21]. Loring, J.M and Taylor, C.K. (2008), Shareholder Activism: Directorial Responses to Investors' Attempt to Change the Corporate Governance Lanfscape in Clarke, T. and dela Rama, M (eds) (2008), The Fundamentals of Corporate Governance, Volume 2: Boards and Directors, SAGE Publications, London. Pp.37-51

[22]. Marshal, A. (1920), Industry and Trade, London. Macmillan.

[23]. NEPAD (2006), The New Partnership for Africa's Development: Domesticating NEPAD in Nigeria, Activities and Programmes of NEPAD Nigeria 2003-2006, Abuja. National Planning Commission

[24]. OECD (2003), Report on the Observance of Standards and Codes (ROSC): Corporate Governance Country Assessment, Republic of South Africa, July. Pp.4-14

[25]. Olaniyi, C.O. (2008), An Examination of the Nigerian Public Service Pension, Google Search April 14, 2007 , p. 1

[26]. Otinche, S. I. (2012), Pension Administration in Nigeria: Issues in Theory and Practice, Abuja. Marvellous Printer.pp.113; 118; $134 ; 220 ; 230 ; 150$

[27]. Ozo-Eson, P. I. (2005) "Pension Reforms and Economic Recovery" The Quest for Social SecurityAbuja. Nigeria Social Insurance Trust Fund. Pg.72

[28]. PRA (2004), Pension Reform Act 2004, Abuja. National Pension Commission. Pp 36- 51, 113

[29]. Rachel, K. (n. d), Corporate Governance: The Foundation for Corporate Citizenship and SustainableBusinesses,Global Corporate Governance Forum. IFC/ World Bank

[30]. Smith, A. (1776), An Inquiry into the Nature and Causes of Wealth of Nations, New York. Random House.

[31]. Stiles, P. And Taylor, B. (2008), The Strategic Role of the Board in Clarke, T. and dela Rama, M (eds)(2008), The Fundamentals of Corporate Governance, Volume 2: Boards and Directors, SAGE Publications, London. Pp.84-110

[32]. Sykes, A. (1994), "Proposal for International Competitive Corporate Governance in Britain and America"Corporate Governance Vol. 2 No 4. Pp.187-195

[33]. Vitas, O. (1996), Pension Funds and Capital Market Viewpoint, Washington D.C. The World Bank. February

[34]. William, S. (2011), "Jonathan Signs Financial Reporting Council Bill” Daily Trust, Thursday, July 21. 